\title{
エリトロシンラクトンを用いた酒類中のエタノールの吸 光光度定量
}

\author{
山本大二郎，塚田 正道，佐藤 大英 ${ }^{\circledR *}$
}

(1990 年 11 月 2 日受理)

\begin{abstract}
酸性色素エリトロシンを用いて酒類中のエタノールの定量を試みた。酸性色素エリトロシンは酸性水 溶液中でラクトン型となり, 疎水性有機溶媒中に無色の化学種として抽出される.この抽出液にエ夕ノ一 ルを添加すると，オレンジ色に発色する。この溶液を水と振り混ぜると，水相と有機相の両方に発色物 が分配される．この水相を比色定量することにより，エ夕ノ一ルの定量も可能だが，温度による分配の 影響や，酒類の色の影響なども考慮しなければならず繁雑である．水相に $2 \mathrm{M}$ の塩酸を加えることに より, 発色物の水相への移行が抑えられ, 有機相の吸光度測定で着色酒類でもこの方法で簡単に定量で きることが分かる．実際の分析の結果，酒類のラベル表示程度の二けたの精度で，満足のいく結果が得 られた。
\end{abstract}

\section{1 緒言}

酒類中のエタノールの分析法としては, 比重法や GC が用いられているリ．最近になって，アルコールオキシ ダーゼを用いた酵素電極による分析法"2), アルコールデ ヒドロゲナーゼ固定化醅素カラム吸光 FIA と醅素法を 組合わせた分析法 ${ }^{3)}$, 閉回路電位測定法による洋酒中の エタノールの分析法 ${ }^{4)}, 2304 \mathrm{~nm}$ の近赤外線吸収を用い る方法 ${ }^{5)}$, 短波長 $(700 \sim 1100 \mathrm{~nm})$ 近赤外線吸収を用い る方法 も試みられた。著者の一人 (山本) は先に, 当 時としては実用的でなかったが， OH 基の伸縮振動の第 一倍音の近赤外吸光法を用いる方法で，簡単に定量でき ることを報告した ${ }^{7}$. しかし，分析法の中で最も簡単な 光電比色法による研究は長く行われてこなかったが, 最

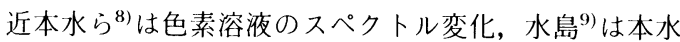
らの方法を利用して簡易比色計によるアルコールの定 量, 又山本ら ${ }^{10)}$ はローダミン B ラクトンがアルコール 類と反応して発色する現象を利用して，比色法も簡単に 行えることを報告した。

著者らは更に酸性色素のエオシンやエリトロシンのラ クトンが疎水性有機溶媒中でエタノールと反応して発色 することを見いだし，満足のできる定量分析法を考案し た。エオシンやエリトロシンの酸性水溶液に疎水性の四

* 明治大学農学部: 214 神奈川県川崎市多摩区東三田 $1-1-1$
塩化炭素, クロロホルム, 1,2-ジクロロエタンなビの有 機溶媒を加えて振り混ぜると，それらの色素はラクトン 型の無色の化学種として溶媒相に移行する．この液にア ルコール類が添加されると, $480 \mathrm{~nm}$ 付近に吸収極大を 有する発色が見られる.この発色を利用して，酒類中の エタノールの定量を試みた。

分析には次の三法が考えられる.

（1）エ夕ノ一ル水溶液（酒）と，有機溶媒を振り混 ぜあらかじめエ夕ノールを抽出し，溶媒相とラクトン溶 液を反応させて発色させる.

（2）エ夕ノール水溶液とラクトン溶液を振り混ぜ る.このとき, エ夕ノールは有機相に分配され，発色す る. それと同時に逆抽出の形で, 水相に色素が移り，水 相をも着色する.そのいずれかの相を比色定量する．た だし, 水相の比色定量は, 着色酒類には適用できない.

（3）（2）の方法で, 塩酸を加え, 水相に色素が抽出 されないようにして, 有機相の発色で比色定量する.

これらのうち，スペクトルその他の基礎的事項の研究 には( 1 )を, 実際の酒類中のエ夕ノールの定量には( 3 ) を使用した。（3)の方法で, 有色酒類を含め5〜60 度 の酒類のアルコール度数を簡単な操作で定量を行うこと ができた。

色素としては, エオシンよりエリトロシンのほうが, 大きい吸光度を与えたので，エリトロシンを使用した。 


\section{2 実験}

\section{$2 \cdot 1$ 試 薬}

水: 水道水をオルガノ G-10 型カートリッジ純水器で 脱イオン水とし岩城硝子製 Still-1P 型蒸留装嵮で蒸留 し，更に Barnsted 製 NANO pure II で，超純水（比抵 抗＞18 M $\Omega$ ）としたものを用いた。

試薬：エリトロシン（以下 $\operatorname{Er}$ と略記）は，東京化成 工.業製，エ夕ノールは国産化学製の試薬特級 (99.5\%) のものを, 有機溶媒は市販の試薬特級をそのまま用い た.

\section{$2 \cdot 2$ 装}

紫外及び可視部吸収スペクトル：日立 557 形二.波長 分光光度計に東京理化器製 $\mathrm{CH}-250$ 型サーミス夕恒温 槽を併用して使用した。

赤外吸収スペクトル：日立 I-5020 型フーリエ変換赤 外分光光度計

比色定量：日立 U-1100 型分光光度計を使用した。

$$
3 \text { 結果亡考察 }
$$

\section{$3 \cdot 1$ ラクトン型溶液及び着色溶液の吸収スペクトル}

エオシン，エリトロシンともに酸性溶液（濃厚なとき は赤褐色の沈殿を生じる) を踈水性有機溶媒（ベンゼ ン，へキサン，1,2-ジクロロエタン，クロロホルムな ビ）で抽出すると，ラクトン型となって有機溶媒相に抽

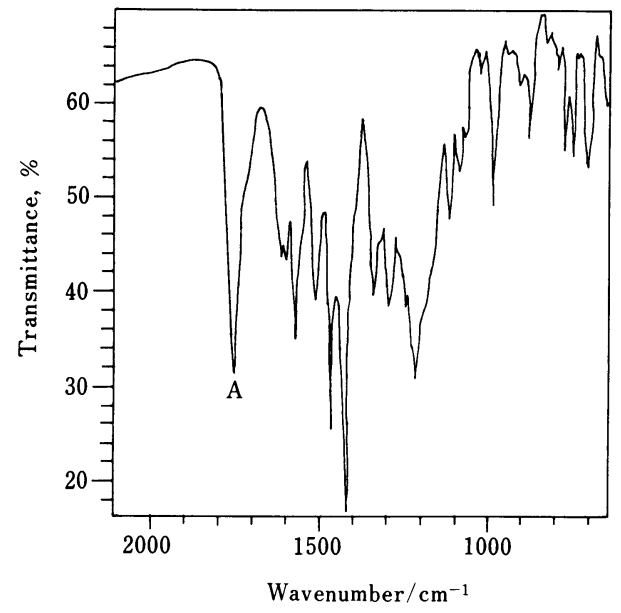

Fig. 1 Infrared spectrum of sample precipitated from hydrochloric acid solution of erythrosine

Sharp peak at A, $1770 \mathrm{~cm}^{-1}$, shows existence of carbonyl $(\mathrm{C}=\mathrm{O})$ in saturated $\gamma$-lactone.
出される. まずラクトン型の有無の確認を行った。

Fig. 1 はエリトロシン水溶液を強塩酸酸性として得ら れた沈殿の赤外吸収スペクトルである. $1770 \mathrm{~nm}$ 付近に ピークが見られることにより飽和 $\gamma$-ラクトンが確認さ れる11). その沈殿をへキサンに溶解させたものの紫外 部吸収曲線はFig. 2a のようである。このスペクトルは

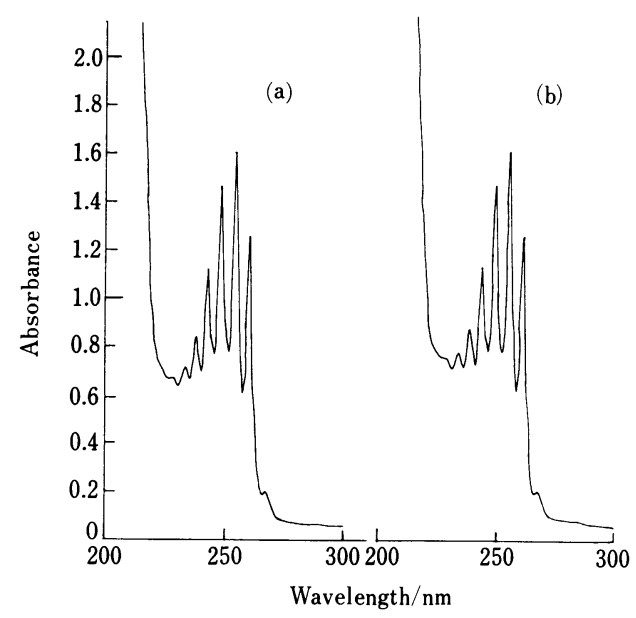

Fig. 2 UV absorption spectra of the solutions (a) a precipitate dissolved in hexane; (b) extracted in hexane from hydrochloric acid solution of the dye

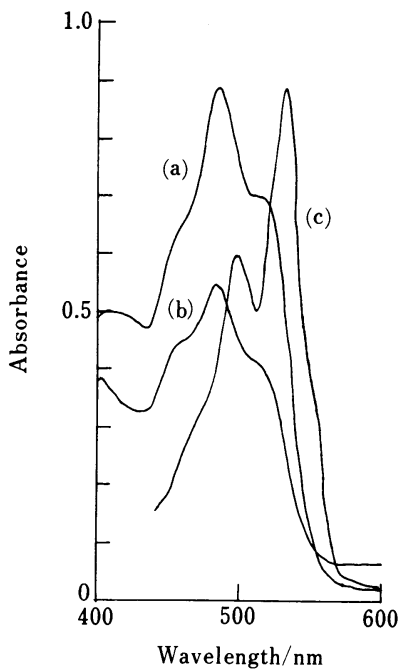

Fig. 3 Absorption spectra of colored solutions with $\mathrm{EtOH}$ and amine

(a) precipitate dissolved in 1,2-dichloroethane; (b) extracted of 1,2-dichloroethane; (c) tributylamine 
ヘキサンに，エリトロシン水溶液を塩酸酸性とし，抽出 させたものの紫外部吸収スペクトル（Fig. 2b）に一致 する.エリトロシンラクトンを有機溶媒相に抽出させた ものに，エタノールを添加すると発色する. 可視部吸収 スペクトルは Fig. 3a のようである.このスペクトルは 酸性溶液で生じる沈殿を分離, 乾燥し, 1, 2-ジクロロエ タンに溶解 (無色), それにエタノールを添加して得ら れる着色物質の吸収スペクトル（Fig. 3b）に一致す る. 以上の結果からも，抽出液はラクトン型になってい ると確認できる.

\section{$3 \cdot 2$ エタノールの定量法についての考察}

エタノールで発色するラクトンはエオシンもエリトロ シンも共に黄褐色を呈したが, 同一着色溶液では同一濃 度のエタノールに対して，エリトロシンのほうが大きい 吸光度を与えるので, 以後の実験にはエリトロシンを使 用した。

酒類中のエ夕ノールの分析法には次の 3 種の方法が 考えられる。

(1)ラクトン溶液と酒類のジクロロエタンなどの有機 溶媒抽出溶液とを混合し, 着色物の吸光度を求める.

（2）酒類とラクトン溶液を合わせ振ると, 水相が着 色するので, その吸光度を求める.

（3）酒類を塩酸酸性とし，エリトロシン溶液を加 え, ジクロロエタンなどの溶媒を加えて振る. 有機溶媒 相が着色するので, その吸光度を求める.

これらの中で, (2) は着色酒類には利用できないの で，考慮しなかった（1)，(3)のいずれを採るかは，先 にローダミン B ラクトンを利用した定量のときに, 酒 類を強アルカリ性にしてローダミン B を添加し, 有機 溶媒抽出を行ったところ, 有機相が着色し定量が簡単に できたので9)，全く同様な発想で(3)を行ってみたとこ ろ，(1)よりも非常に簡単に定量が行えることが分か り，(3)法を採用することにした．以下色素としてエリ トロシンを使用し，(3)法を用いての定量を記す。

\section{3 •3 エリトロシンによるエタノールの定量}

共栓付き試験管に, $\operatorname{Er}$ 水溶液 $\left(1 \times 10^{-3} \mathrm{M}\right)$ を取 り, 塩酸酸性とし, 有機溶媒, エ夕ノールを添加して, 振り混ぜ，静置後有機相を分取することにより，エ夕 ノールが定量できた．可視部吸収スペクトルは，Fig. 3a に示したものと一致し， $\lambda=484 \mathrm{~nm}$ 付近に吸収極大 を持つことが分かった。

\section{(a) 有機溶媒の選択}

$\mathrm{Er}$ 水溶液 $\left(1 \times 10^{-3} \mathrm{M}\right)$ を $5 \mathrm{~cm}^{3}, 6 \mathrm{M}-\mathrm{HCl}$ を 2
Table 1 Selection of organic solvents

\begin{tabular}{lc}
\hline \multicolumn{1}{c}{ Organic Solvents } & Absorbance $(\lambda=484 \mathrm{~nm})$ \\
\hline Dichloromethane & 0.763 \\
1,1-Dichloroethane & 0.510 \\
1,2-Dichloroethane & 0.502 \\
Chloroform & 0.839 \\
Toluene & 0.255 \\
Benzene & 0.528 \\
Carbontetrachloride & - \\
\hline
\end{tabular}

Organic solvent : $5 \mathrm{~cm}^{3} ; \operatorname{Er}\left(1 \times 10^{-3} \mathrm{M}\right): 2 \mathrm{~cm}^{3}$; HCl $(6 \mathrm{M}): 2 \mathrm{~cm}^{3}$; Ethanol $(40 \%): 5 \mathrm{~cm}^{3}$

Table 2 Influence of the volume of dye solution on the color development

\begin{tabular}{cccc}
\hline $\begin{array}{c}\mathrm{Er} / \\
\mathrm{cm}^{3}\end{array}$ & $\begin{array}{c}\text { Blank } \\
\text { value }\end{array}$ & $\begin{array}{c}40 \% \text { ethanol } \\
\text { absorbance }\end{array}$ & $\begin{array}{c}60 \% \text { ethanol } \\
\text { absorbance }\end{array}$ \\
\hline 2 & 0.046 & 0.695 & 1.368 \\
3 & 0.048 & 0.805 & \\
4 & 0.053 & 0.920 & 2.250 \\
5 & 0.073 & 1.006 & \\
6 & 0.073 & 1.048 & \\
7 & 0.082 & 1.098 & \\
8 & 0.091 & 1.094 & \\
\hline
\end{tabular}

Er : $1 \times 10^{-3} \mathrm{M}$ chloroform : $5 \mathrm{~cm}^{3} ; \mathrm{HCl}(6 \mathrm{M}): 2$ $\mathrm{cm}^{3} ; \lambda=484 \mathrm{~nm}$

$\mathrm{cm}^{3}, 40 \%$ エ夕ノールを $5 \mathrm{~cm}^{3}$, 有機溶媒を $5 \mathrm{~cm}^{3}$ 加 え， $\lambda=484 \mathrm{~nm}$ における吸光度を比較した。結果は Table 1 に示すようであり，クロロホルムを用いた場合 が最も良好な結果が得られた。

（b）色素溶液の量の影響

共栓付き試験管に，40\%エタノール $5 \mathrm{~cm}^{3}$, クロロホ ルム $5 \mathrm{~cm}^{3}, 6 \mathrm{M}-\mathrm{HCl} 2 \mathrm{~cm}^{3}$ をとり, 色素として $\mathrm{Er}$ $\left(1 \times 10^{-3} \mathrm{M}\right)$ 水溶液を加え, その $\mathrm{Er}$ 水溶液の量を $2 \sim 8 \mathrm{~cm}^{3}$ に変化させて, 吸光度の変化を見た（Table 2).色素量を増加させると, 吸光度は増大するが，から 試験值も増加する. 更に, 実用化を考え, エ夕ノール $60 \%$ での吸光度が, ランベルトーベールの式に従う吸光 度範囲に収まるようにと考え, 色素量は, $2 \mathrm{~cm}^{3}$ を用い ることにした。

\section{(c) 塩酸濃度の検討}

添加する塩酸の濃度を変化させて, 吸光度の変化を測 定した。加える塩酸の量を $2 \mathrm{~cm}^{3}$ とし, その濃度を 0.1 , $0.4,0.6,0.8,1,2,4,6,12 \mathrm{M}$ と変化させた Fig. 4 に示 すように塩酸濃度 $0.6 \mathrm{M}$ から $2 \mathrm{M}$ までの間で一定かつ 


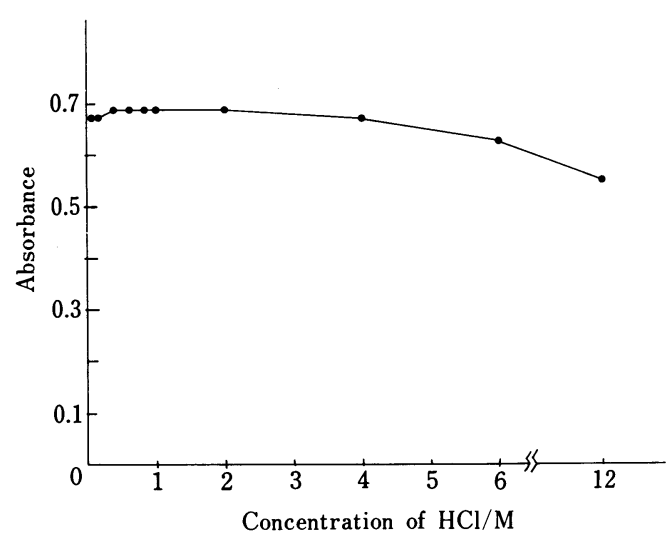

Fig. 4 Absorbance of different concentrations of hydrochloric acid

$\operatorname{Er}\left(1 \times 10^{-3} \mathrm{M}\right): 2 \mathrm{~cm}^{3} ; \operatorname{HCl}(2 \mathrm{M}): 2 \mathrm{~cm}^{3}$; Chloroform : $5 \mathrm{~cm}^{3}$; Ethanol (40\%): $5 \mathrm{~cm}^{3}$

Table 3 Change of absorbance with temperature

\begin{tabular}{cc}
\hline Temperature $/{ }^{\circ} \mathrm{C}$ & Absorbance \\
\hline 10 & 0.430 \\
20 & 0.415 \\
30 & 0.400 \\
40 & 0.380 \\
\hline
\end{tabular}

Er $\left(1 \times 10^{-3} \mathrm{M}\right): 2 \mathrm{~cm}^{3} ; \quad \mathrm{HCl} \quad(2 \mathrm{M}): 2 \mathrm{~cm}^{3}$; $\mathrm{CHCl}_{3}: 5 \mathrm{~cm}^{3} ; 30 \%$ ethanol : $5 \mathrm{~cm}^{3}$

最大の吸光度を得たので以後実験では $2 \mathrm{M}$ の塩酸を用 いることとした。

(d) 反応生成物の温度変化

$\mathrm{Er}$ 水溶液 $\left(1 \times 10^{-3} \mathrm{M}\right) 2 \mathrm{~cm}^{3}, 2 \mathrm{M} \mathrm{HCl}$ を $2 \mathrm{~cm}^{3}$, ク ロロホルム $5 \mathrm{~cm}^{3}, 30 \%$ エタノール $5 \mathrm{~cm}^{3}$ を振り混ぜ, 有機相を分取し, $10 \sim 40^{\circ} \mathrm{C}$ での吸収スペクトルの変化 を測定した。結果は Table 3 に示すように吸収極大波 長 $\lambda=484 \mathrm{~nm}$ の吸光度は, 温度の上昇に伴って低下し た。

\section{（e）反応の安定性}

次に反応生成物の安定性を検討するため, 有機相を分 取後の同一温度での経時変化を測定した結果を，Table 4 に示した. 時間の経過に伴って吸光度は減少するが, 最初の 30 分で吸光度は $99.6 \%$ までの减少なので, 30 分以内に测定すればよいことが分かった。

(f) 検量線

共栓付き試験管に, $\mathrm{Er}$ 水溶液 $\left(1 \times 10^{-3} \mathrm{M}\right)$ を 2
Table 4 Effect of lapsed time on absorbance at room temperature

\begin{tabular}{ccc}
\hline $\begin{array}{c}\text { Lapsed time/ } \\
\text { min }\end{array}$ & $\begin{array}{c}\text { Absorbance } \\
(\lambda=484 \mathrm{~nm})\end{array}$ & $\begin{array}{c}\text { Relative } \\
\text { ratio, \% }\end{array}$ \\
\hline 0 & 0.730 & 100 \\
30 & 0.727 & 99.6 \\
40 & 0.719 & 98.5 \\
55 & 0.710 & 97.3 \\
70 & 0.704 & 96.4 \\
85 & 0.700 & 95.9 \\
110 & 0.694 & 95.1 \\
120 & 0.692 & 94.8 \\
\hline
\end{tabular}

$\operatorname{Er}\left(1 \times 10^{-3} \mathrm{M}\right): 2 \mathrm{~cm}^{3} ; \mathrm{HCl}(2 \mathrm{M}): 2 \mathrm{~cm}^{3}$; Ethanol $(45 \%): 5 \mathrm{~cm}^{3}$; chlorofrom : $5 \mathrm{~cm}^{3}$

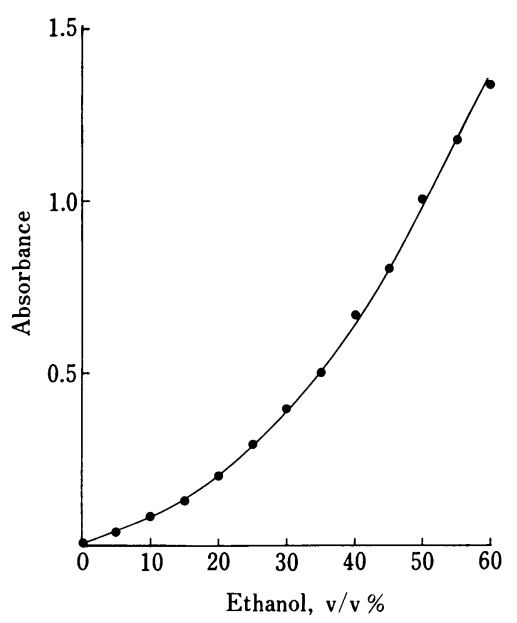

Fig. 5 Calibration curve of EtOH by erythrosine lactone method

Measurement : $484 \mathrm{~nm}$

$\mathrm{cm}^{3}, 2 \mathrm{M} \mathrm{HCl}$ を $2 \mathrm{~cm}^{3}$, クロロホルムを $5 \mathrm{~cm}^{3}$, エ夕 ノール水溶液を $5 \mathrm{~cm}^{3}$ 取りよく振り混ぜる. 約 10 分間 静置し，二相が分離した後に有機相を分取し，日立 U-1100 型分光光度計で波長 $\lambda=484 \mathrm{~nm}$ で用いて吸光 度を測定した。得られた検量線はFig. 5 のようで, 直 線とはならなかった。測定可能な濃度範囲は, エ夕ノー ル 5〜60 v/v\% で再現性よく定量できた. 15，40v/v\% における 5 回測定の相対標準偏差はそれぞれ 3.0, 2.3\% であった．酒類のラベル表示の濃度は二.けけたで,この 程度の精度で満足であろう。

（g）共存物質の影響

本法において妨害を生じやすいと思われる数種のアル 
Table 5 Effect of the co-existent substances on absorbance of the organic phase

\begin{tabular}{lcc}
\hline \multicolumn{1}{c}{ Substances } & Absorbance & $\begin{array}{c}\text { Relative } \\
\text { ratio }(\%)\end{array}$ \\
\hline None (20\% ethanol) & 0.269 & 100 \\
Methanol & 0.280 & 104 \\
1-Butanol & 0.335 & 125 \\
2-Propanol & 0.312 & 116 \\
Isopentyl alcohol & 0.348 & 129 \\
Etylene glycol & 0.282 & 105 \\
\hline
\end{tabular}

Er $\left(1 \times 10^{-3} \mathrm{M}\right): 2 \mathrm{~cm}^{3} ; \quad \mathrm{HCl} \quad(2 \mathrm{M}): 2 \mathrm{~cm}^{3}$; Chloroform : $5 \mathrm{~cm}^{3}$; Measured at $484 \mathrm{~nm}$; Concentration of coexistent substances was $1 \mathrm{v} / \mathrm{v} \%$.

Table 6 Observed values of ethanol contents in liquors

\begin{tabular}{lccc}
\hline \multicolumn{1}{c}{ Species } & Absorbance & $\begin{array}{c}\text { Calculated } \\
\text { value, \% }\end{array}$ & $\begin{array}{c}\text { Labeled } \\
\text { value, \% }\end{array}$ \\
\hline Wine (white) & 0.098 & 13 & $<14$ \\
Wine (rose) & 0.095 & 13 & $<14$ \\
Wine (red) & 0.091 & 13 & $<14$ \\
Nihon-shu A & 0.139 & 16 & $15 \sim 16$ \\
Nihon-shu B & 0.139 & 16 & $15 \sim 16$ \\
Nihon-shu C & 0.129 & 15 & $15 \sim 16$ \\
Shotyu A & 0.296 & 25 & 25 \\
Shotyu B & 0.666 & 40 & 40 \\
Whisky A & 0.562 & 36 & 37 \\
Whisky B & 0.782 & 43 & 43 \\
Gin & 0.887 & 47 & 47.5 \\
\hline
\end{tabular}

コール類を添加した試料の吸光度を測定した. エ夕ノ一 ルを $20 \mathrm{~cm}^{3}$ 取り, Table 5 に示した物質 $1 \mathrm{~cm}^{3}$ を加え て水で全容を $100 \mathrm{~cm}^{3}$ とした。この $5 \mathrm{~cm}^{3}$ を取り，同 様に吸光度を測定した，得られた結果は Table 5 のよ うであった．加えたアルコール類は存在すると考えられ るアルキル基の増加に伴った吸光度の増加を示した。

又, 醸造酒中に含まれると思われる, グルコース，コハ ク酸などの物質は吸光度に影響を与えなかった。

(h) 実試料にて得られた結果

一般的な酒類中のエ夕ノール含量を測定した。試料は 希釈しないでそのまま使用し，上記の方法で定量した。 結果は Table 6 のようであった。アルコール含有率 (v/v\%) はラベル表示の值とよく一致した。

\section{$3 \cdot 4$ 着色物質に対する考察}

エリトロシンラクトンを発色させる物質には 2 群 ある、第1群はエ夕ノールの場合に見られたように $\lambda=484 \mathrm{~nm}$ に吸収極大を有するもの（Fig. 3b）で，例 外はあるが，一般にドナ一数 ${ }^{12)} 14 〜 30$ 程度のものであ る. 定性的ではあるが, 以下のものがこの群に属した. （）内にドナー数を示す.

ジオキサン (14.8), アセトン (17.0), メ夕ノール (19), エタノール (20), テトラヒドロフラン (20), ジメ チルスルホキシド (29.8)

第 2 群はFig. 3c に見られるようなドナー数の大きな アミン類で, 図はトリブチルアミンによる発色を示す.

これらの物質はいずれも酒類に混在すれば，定量の妨 害となることは明らかであるが，現実には考慮の必要は ないと考えられる．エ夕ノールによる着色物質について は構造を知ることはできなかった。

疎水性有機溶媒に抽出された無色のラクトン型エリト ロシンにアルコール類を添加すると発色する現象を利用 して, 酒類中のエタノール濃度を, 簡単な光電比色計に よって，比色定量する方法を考案した．水相を塩酸酸性 にしておくと, 水相での発色はなく, 有機相だけが着色 し, 有色酒類でもこの方法でエ夕ノール濃度の定量が可 能であることを見いだした。ただし検量線に直線性がな く, エタノール濃度の定量はラベル表示の二けた程度の 精度しかなかった。

$\left(\begin{array}{l}1990 \text { 年 } 10 \text { 月, 日本分析化学会 } \\ \text { 第 } 39 \text { 年会において一部発表 }\end{array}\right)$

\section{文献}

1) AOAC, "Official Method of Analysis", pp. 175, 192 (1984). 日本分析化学会編, “分析化学便覧改訂” 版”, p. 1224 (1981).

2）軽部征夫，鈴木周一: “発酵と工業”, 41, 580 (1983).

3) F. Lazaro, M. D. Luque de Castro, M. Valcarcel : Anal. Chem., 59,1859 (1987).

4) 泉生一郎: 化学と教育, 32343 (1984); 片倉勝巳, 泉生一郎: 日化, 1986, 333.

5) 河野澄夫: 化学と生物, 28, 380 (1990).

6) A. G. Cavinato, D. M. Mayes, Zhihong Ge, J. B. Callis : Anal. Chem., 62, 1977 (1990).

7）山本大二郎，丁 保良: 明大農研報, No. 18, 15 (1965).

8）細井康宏, 本水昌二: 分析化学, 37, 301（1988）.

9）水島耕成: 化学と教育, 38, 560 (1990).

10）山本大二郎, 安部卓郎: 明大農研報, No. 78, 65 (1988).

11) R. M. Silverstein G. G. Bassler, T. C. Morrill : "Spectrometric Identification of Organic Compounds", 3rd ed., p. 103 (1974), (John Wiley \& Sons, New York).

12）大滝仁志, 岡田 勲訳: “ドナーとアクセプター 
(溶液反忘の分子間相互作用)”, p. 22 (1986), (学 会出版センター); \{V. Gutmann: “The Donor-
Acceptor Approach to Molecular Interactions", (1978), (Plenum Press, New York)\}.

\section{ڤ̌}

Spectrophotometric determination of ethanol in liquors using erythrosine lactone. Daijiro Yамамото, Masamichi Tsukada and Daiei Sato (Faculty of Agriculture, Meiji University, 1-1-1, Higashi-mita, Tama-ku, Kawasaki-shi, Kanagawa 214)

Spectrophotometric determination of ethanol in liquors using erythrosine lactone was examined. Erythrosine was extracted from acidic solution into hydrophobic organic solvents as a colorless species of lactone type. An orange color was developed by the addtion of a small quantity of alcohol into the extract. When this solution was mixed with water, the color was distributed into both phases, the water and the organic solvent. Photometric measurement was carried out using the water phase to determine the content of ethanol. This method had two weak points. One was lack of reproducibility owing to the temperature dependence of the distribution. The other was that this method was not able to be applied to colored liquors. Another method was investigated. When an aqueous solution of approximately $2 \mathrm{M} \mathrm{HCl}$ was added to the liquor phase, colored species of erythrosine remained in the organic phase. Photometric determination was performed by using the organic solvent phase. By this method the ethanol content of colored liquors was determined without distilling. The analytical results on some liquors agree well with the labeled values on bottles.

(Received November 2, 1990)

\section{Keyword phrases}

spectrophotometric determination of ethanol in liquors; chloroform extraction of ethanolerythrosine complex. 